Bangladesh J. Bot. 44(2): 285-292, 2015 (June)

\title{
EFFECTS OF CARBON AND NITROGEN SOURCES ON PRODUCTION OF PROTEASES BY BACILLUS SUBTILIS IC-5
}

\author{
Sereen Gul ${ }^{1}$, Mujeeb Ur Rahman*, Mohammad Ajmal, \\ Abdul Kabir Khan AchaKzai and Asim Iqbal ${ }^{2}$ \\ PCSIR Laboratories, P.O. Box 387, Mastung Road, Quetta, Balochistan, Pakistan \\ Key words: Carbon, Nitrogen, Production, Proteases, Bacillus subtilis
}

\begin{abstract}
The effects of various carbon and nitrogen sources were evaluated on production of proteases by Bacillus subtilis IC-5. Both type and concentration of carbon and nitrogen sources influenced the production of proteases. Among the carbon sources glucose was found to be the most effective. It gave maximum production at $2 \% \mathrm{w} / \mathrm{v}$ concentration i.e., 1875 and $950 \mathrm{U} / \mathrm{ml}$, alkaline and neutral protease, respectively. The response of Bacillus subtilis IC-5 towards synthesis and excretion of enzymes varied with the type of nitrogen sources. The addition of organic nitrogen sources to basal medium repressed the synthesis of proteases while the addition of inorganic nitrogen source such as sodium nitrate was found to be the best stimulating for alkaline and neutral protease synthesis. Sodium nitrate enhanced the production up to 62.40 and $10.52 \%$ of alkaline and neutral protease, respectively against w.r.t. control.
\end{abstract}

\section{Introduction}

Industrial enzymes are obtained from three major sources i.e., plant, animal and microorganisms. The extraction of enzymes from plant or animal source is limited and seasonal in case of plant source. However, production of enzymes by fermentation process is unlimited and can be produced round the year. Proteolytic enzymes are ubiquitous in occurrence, being one of the largest and most important groups of enzymes which accounts for about $30 \%$ of total worldwide production (Horikoshi 1996) and about $60 \%$ of sale (Beg et al. 2003). The extracellular proteases have commercial value and find multiple applications in various industrial sectors. The detergent industry has emerged as one of the major consumers of hydrolytic enzymes working at higher $\mathrm{pH}$ (Adinarayana et al. 2003). It is used as cleansing additives in detergents to facilitate the release of proteinacious materials in stains due to grime, blood, milk, etc (Olajuyigbe and Ajele 2005). Proteolytic enzymes applied in other industries are food, pharmaceutical, leather, silk and recovery of silver from used X-ray films (Prakasham et al. 2002). Proteases are produced by a wide range of microbes i.e., bacteria, mould and yeast (Gupta et al. 2002). Among bacterial strains of Bacillus sp. dominate the industrial quarters.

The extracellular protease production by microorganisms is greatly influenced by media components especially carbon and nitrogen sources being the main energy and growth promoting factors (Kole et al. 1988). The selection of cost effective nutrients (carbon and nitrogen) is of utmost desire for optimum production of enzymes (Varela et al. 1996). In present study, the effects of carbon and nitrogen sources and their concentrations on production of proteolytic enzymes by Bacillus subtilis were investigated.

*Author for correspondence: <mujeeb.butt@hotmail.com>. ${ }^{1}$ Department of Botany, University of Balochistan, Quetta, Balochistan, Pakistan. ${ }^{2}$ Department of Zoology, University of Balochistan, Quetta, Balochistan, Pakistan. 


\section{Materials and Methods}

The bacterial strain Bacillus subtilis IC-5, inoculum preparation and fermentation procedure was adopted as by Gul et al. (2008).

The effects of carbon sources arabinose, fructose, maltose, mannose, starch, sucrose and xylose on protease production were investigated. The basal medium devoid of carbon source served as control. The effects of different concentrations $(10,20$ and $30 \mathrm{~g} / \mathrm{l})$ of the carbon sources in the medium were also investigated.

The effects of nitrogen sources on protease production were studied by adding in basal medium at the concentration of $10 \mathrm{~g} / \mathrm{l}(\mathrm{W} / \mathrm{V})$, individually. Effects of concentrations studied up to $30 \mathrm{~g} / \mathrm{l}$ of these nitrogen sources were also studied. Organic nitrogen sources were casein, casein hydrolysate, meat extract, peptone, tryptone, and yeast extract, Whereas, Inorganic nitrogen sources were potassium nitrate, sodium nitrate and calcium nitrate and ammonical nitrogen sources were ammonium carbonate, ammonium chloride, ammonium molybdate, ammonium oxalate, ammonium sulphate and ammonium phosphate.

The activity of proteolytic enzymes was assayed by the method of Horikoshi (1971). One unit of proteolytic activity was defined as the amount of enzyme required to liberate TCA soluble material equivalent to $1.0 \mu \mathrm{g}$ of tyrosine from casein per min at $\mathrm{pH} 7.0$ for neutral protease and at $\mathrm{pH} 11.5$ for alkaline protease at $37^{\circ} \mathrm{C}$.

\section{Results and Discussion}

Results presented in Fig. 1 showed that glucose was the best carbon source for Bacillus subtilis IC-5 for producing proteolytic enzymes. In presence of glucose this Bacillus subtilis IC-5 produced $1875 \mathrm{U} / \mathrm{ml}$ alkaline and $950 \mathrm{U} / \mathrm{ml}$ neutral protease. Xylose showed the lowest production. Our results are in conformity with previous studies that protease production reached to maximum when glucose is added to the medium (Andrade et al. 2002) and it induces high protease activity in stationary phase (Deane et al. 1986). The presence of carbon sources in the

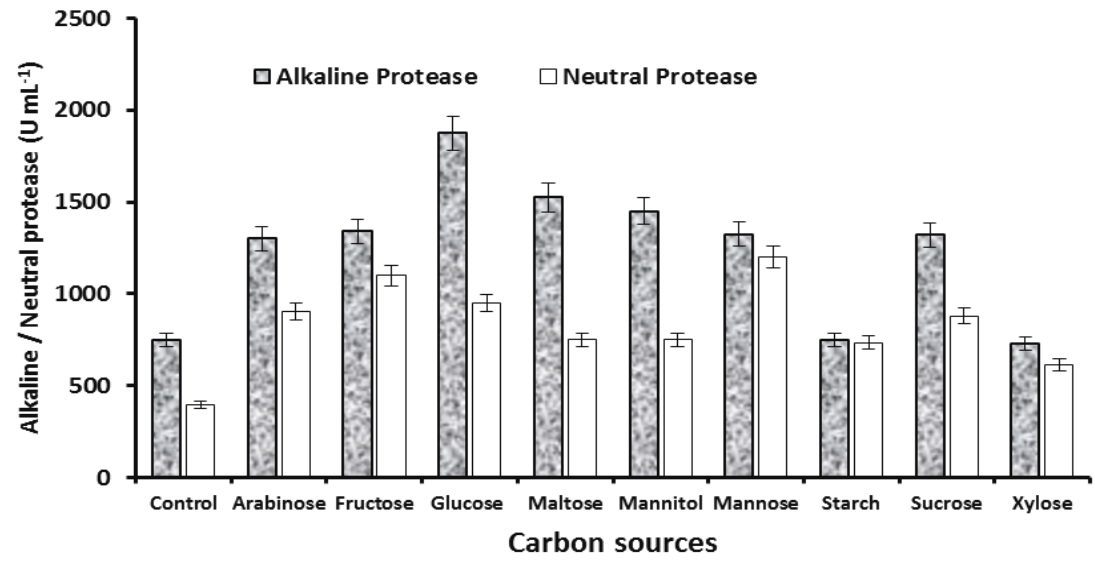

Fig.1. Effects of various carbon sources on production of proteases by Bacillus subtilis IS-5.

medium is reported to be essential for enzyme production in some microorganisms (Homma et al. 1993) but inhibitory to others (Joo et al. 2002). The results depicted in Fig. 2 showed that the carbon sources favor the production of enzymes up to certain concentration only. The response of the increase in concentration of all carbon sources in fermentation medium towards production of 
alkaline and neutral proteases was more or less same. Maximum increase in alkaline protease $(1875 \mathrm{U} / \mathrm{ml})$ and neutral protease $(950 \mathrm{U} / \mathrm{ml})$ were observed at $2 \%$ of glucose. In presence of xylose the increasing production trend of both the enzymes was observed only up to $1 \%$ concentration. The present study also revealed that the production of proteolytic enzymes by Bacillus subtilis IC-5 not only depends upon the kind of carbon source but also the concentration of carbon source in the medium. Catabolite repression in response to carbon source availability (Magasanik 1961) is one of the regulatory mechanisms which govern the synthesis of extracellular enzymes. The catabolite repression of enzymes has been reported by Heineken and O'Conner (1972) in Bacillus subtilis. The proteolytic enzymes synthesis is controlled by availability of carbon sources in the fermentation medium (Lambert et al. 1997). The regulation of extracellular protease secretion by readily absorbable carbohydrates is well documented for several bacterial species (Litchfield and Prescot 1970).
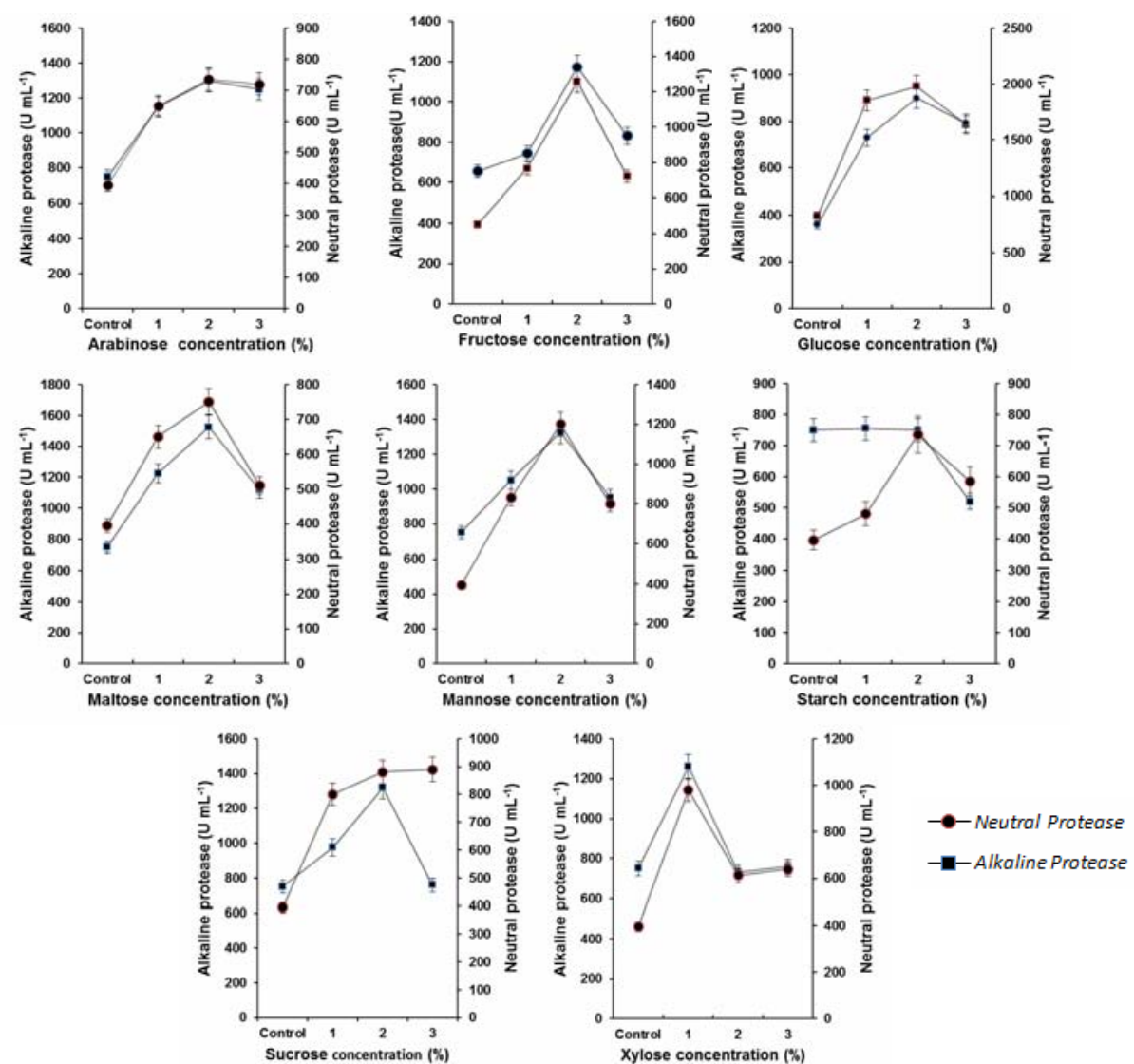

Fig. 2. Effects of different concentrations of various carbon sources on production of proteases by Bacillus subtilis IS-5.

The effects of organic nitrogen sources were evaluated by adding $1 \% \mathrm{w} / \mathrm{v}$ to the basal medium. All the organic nitrogen sources inhibited/reduced the production of proteases (Fig. 3). The overall reduction in the production of alkaline and neutral proteases against to control on addition of organic nitrogen source was in the range of 10.13 to 40.00 and 0.0 to $13.65 \%$, respectively. 


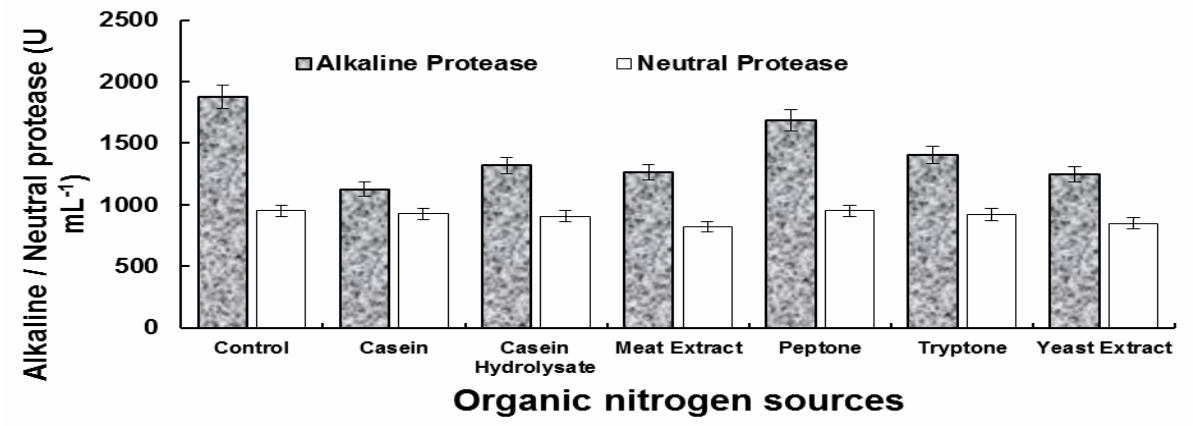

Fig. 3. Effects of various organic nitrogen sources on production of proteases by Bacillus subtilis IS-5.
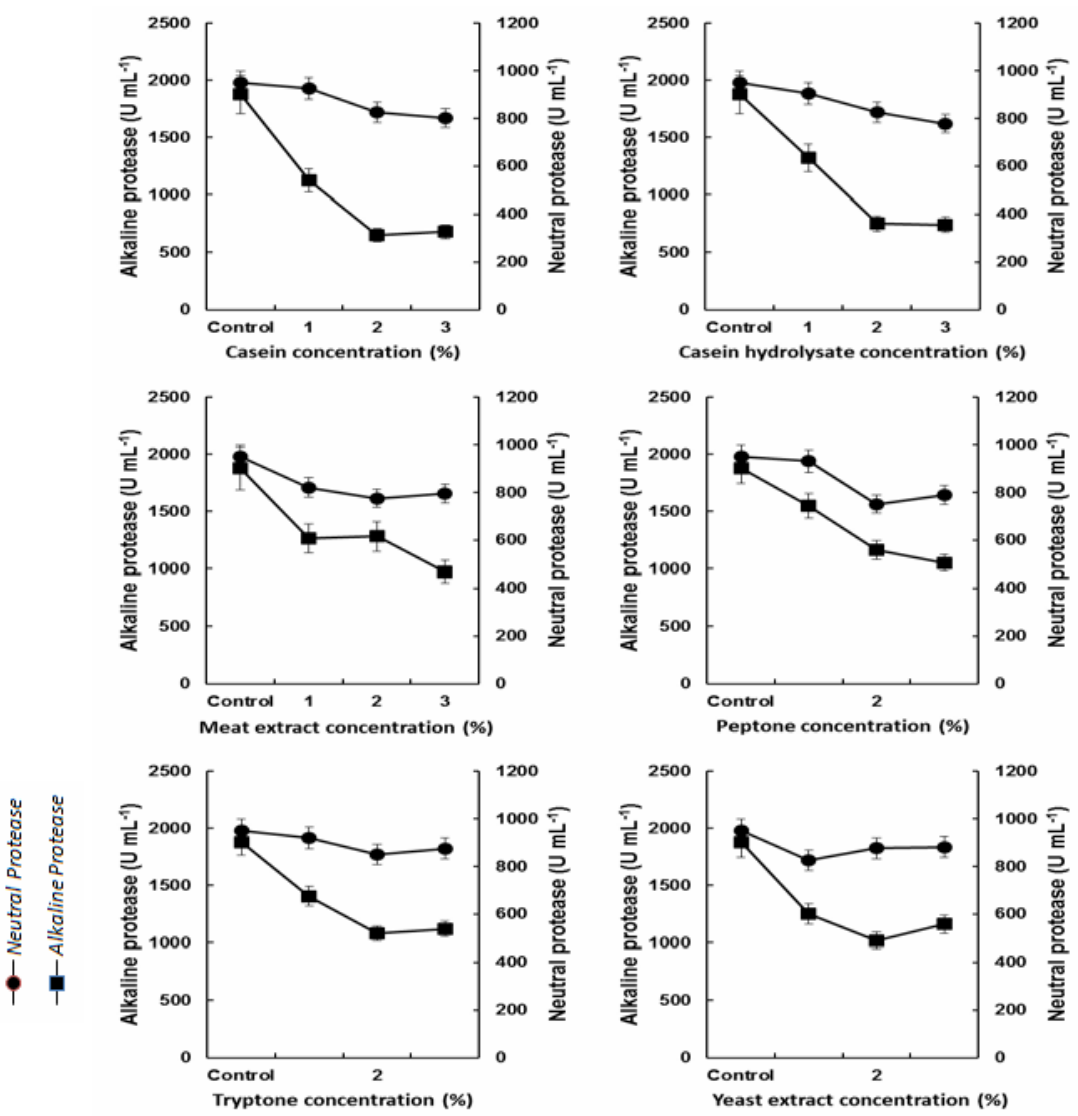

Fig. 4. Effects of different concentrations of various organic nitrogen sources on production of proteases by Bacillus subtilis IS-5.

The effects of increase in concentration of organic nitrogen sources in the fermentation medium on production of proteolytic enzymes were presented in Fig. 4. It revealed that decrease in production was more pronounced in case of alkaline protease than neutral protease on increase in concentration of all organic nitrogen sources in the basal medium. As the bacteria used in the present studies is a proteolytic one, probably, it hydrolyzed the added proteins and produced such 
amino acids which inhibited the synthesis of proteolytic enzymes. An increase in concentration of amino acids decreased the synthesis of proteases and could be restored by their removal (Moracova and Chaloupka1984).

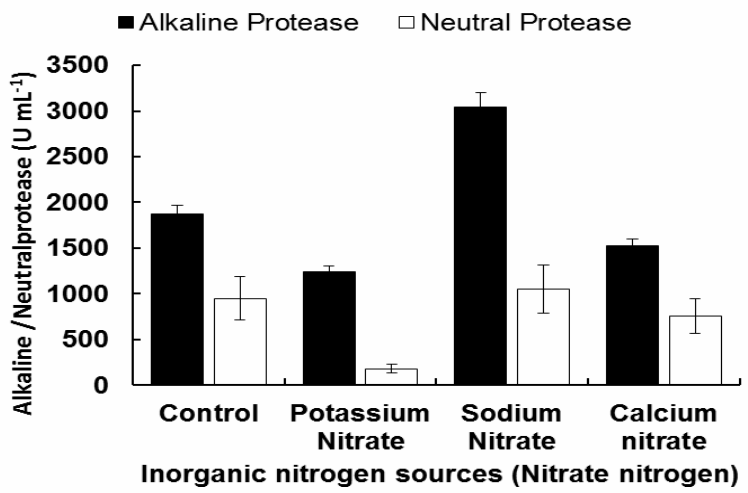

Fig. 5. Effects of various inorganic nitrate nitrogen sources on production of proteases by Bacillus subtilis IS-5.
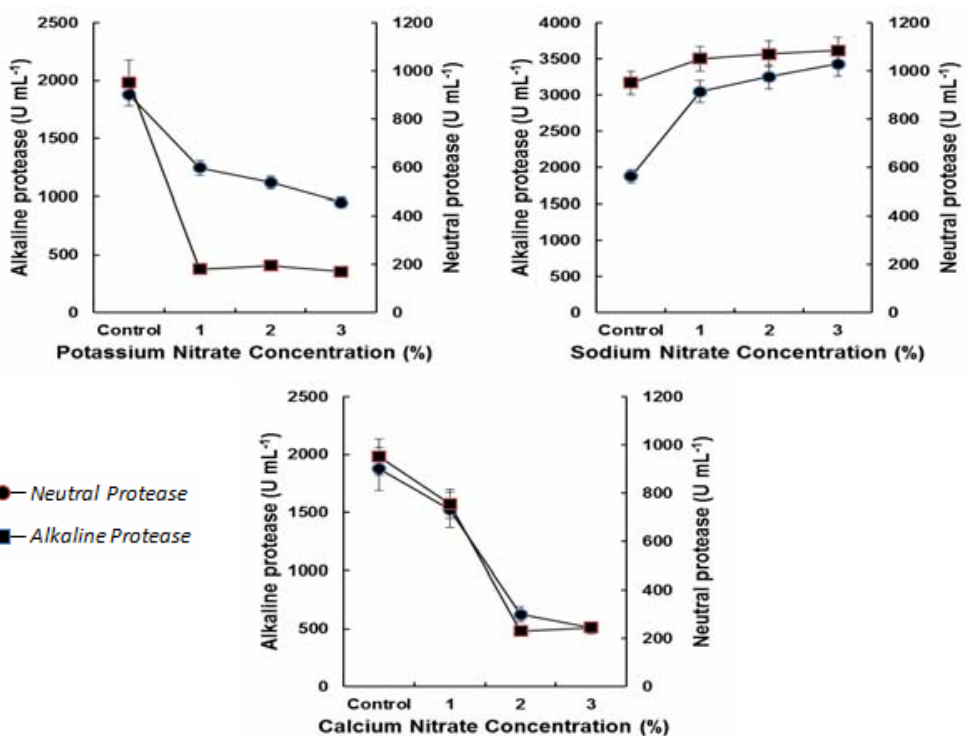

Fig. 6. Effects of different concentrations of various inorganic nitrate nitrogen sources

on production of proteases by Bacillus subtilis IS-5.

The Fig. 5 showed that only sodium nitrate as inorganic nitrogen source had stimulatory effect on the production of both the proteases. It has increased the production 62.40 and $10.52 \%$ against control, of alkaline and neutral protease, respectively. The other sources exerted negative effect on production of both the proteases. Maximum reduction in synthesis of proteases was recorded on addition of potassium nitrate i.e. 33.6 and $81.05 \%$ against control for alkaline and neutral protease, respectively. The increase in concentration of sodium nitrate further increased the production of alkaline and neutral protease up to 3320 and $1085 \mathrm{U} / \mathrm{ml}$ at 3\% w/v concentration. The increase concentration of other nitrogen sources did not have considerable effect (Fig. 6). The alkalophilic 
Bacillus sp. JB99 produced high amount of protease by utilizing $\mathrm{NaNO}_{3}$ as nitrogen source (Johnvesly and Naik 2001). Sodium nitrate induces, stimulates and prevents the decrease in protease activity caused by the addition of glucose (Takii et al. 1990, Tsuchiya and Kimura 1984).

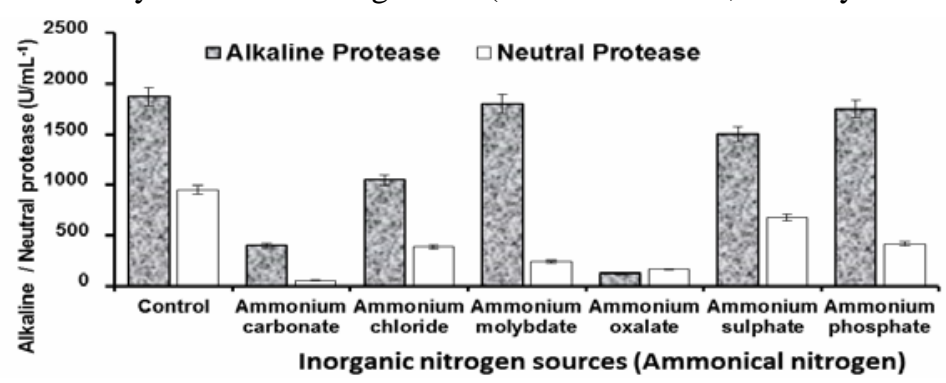

Fig. 7. Effects of various inorganic ammonical nitrogen sources on production of proteases by Bacillus subtilis IS-5.
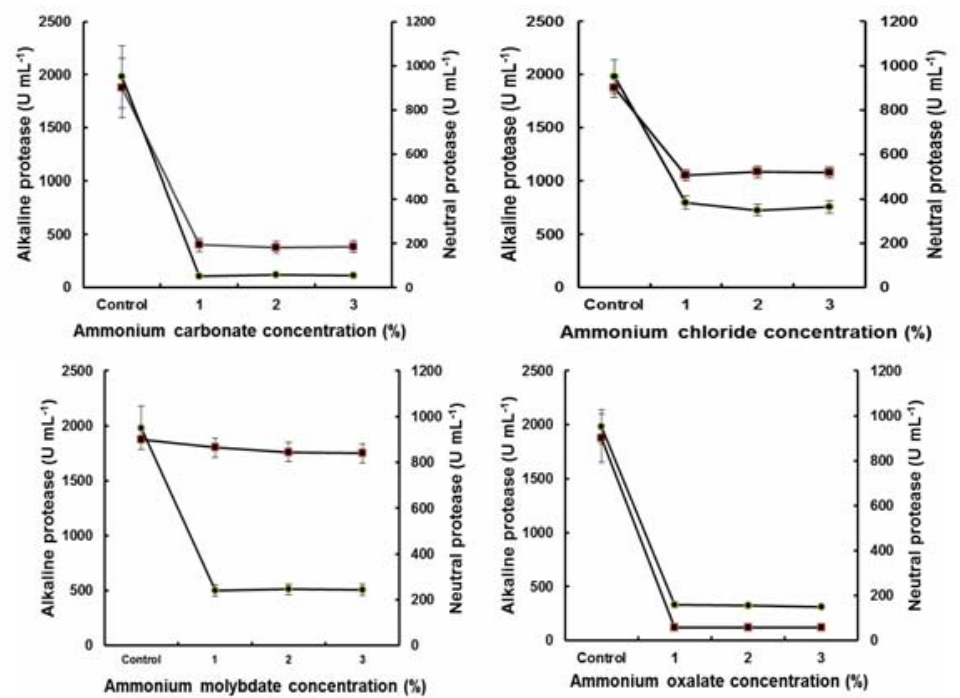

- Neutral Protease

-Alkaline Protease
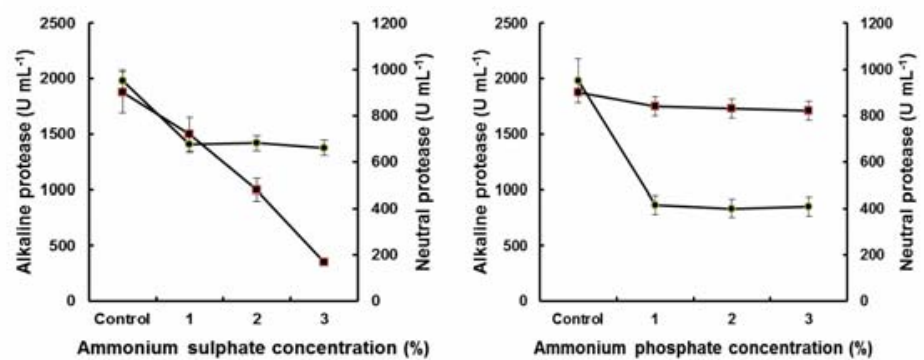

Fig. 8. Effects of different concentrations of various inorganic ammonical nitrogen sources on production of proteases by Bacillus subtilis IS-5.

The Fig. 7 showed that ammonical nitrogen sources had inhibitory effect on synthesis of proteolytic enzymes. This was perhaps due to the inability of bacterium to utilize ammonia in the medium. Such effect of ammonical nitrogen has also been observed for Bacillus cereus (Norazizah et al. 2005). The reduction in synthesis of proteases was up to $94 \%$ with respect to control. These 
results also revealed that ammonium molybdate was the least inhibitor for alkaline and ammonium sulphate for neutral protease. The increase in concentration of ammonium salts in the medium did not have beneficial effect (Fig. 8). Ammonium ion control and repressed the proteolytic enzymes by checking the formation of spores and their effectiveness was higher on enzymes synthesized at the end of bacterial growth phase (Farias et al. 1996).

\section{References}

Adinarayana, K and Ellaiah P 2003. Production of alkaline protease by immobilized cells of alkalophilic Bacillus sp. J. Sci. Ind. Res. (India) 62: 589-592.

Andrade VS, Sarubbo LA, Fukushima K, Miyaji M, Nishimura K and Takaki GM 2002. Production of extracellular proteases by Mucor circinelloides using D-glucose as carbonsources/substrate, Brazillian J. Microbiol. 33: 106-110.

Beg KB, Sahai V and Gupta R 2003. Statistical media optimization and alkaline protease production from Bacillus majavensis in a bioreactor. Process Biochem. 39: 203-209.

Casida, LE Jr 1968. Industrial microbiology, Wiley Eastern Limited, New Delhi, pp. 398-399.

Deane SM, Robb FT and Woods DR 1986. Isolation and characterization of VIbrio alginolyticus mutant that over produces extracellular proteases. J. Gen. Microbiol. 132: 893-898.

Farias MS, Rollan GC and De-Nadra MCM 1996. Influence of nutritional factors on the protease production by Leuconostoc oeno from wine. J. Appl. Bacteriol. 81: 398-402.

Ferrero MA, Castro GR, Abate CM, Baigori MD and Sineriz F 1996. Thermostable alkaline proteases of Bacillus licheniformis MIR 29: isolation, production and characterization. Appl. Microbiol. Biotechnol., 45: 327-332.

Gul S, Rahman M, Achakzai AKK and Khan K 2008. Production of extracellular protease by locally isolated Bacillus subtilis IC-5 using agriculture by-products. J. Chem. Soc. Pak. 30: 900-906.

Gupta R, Beg QK and Loranz P 2002. Bacterial alkaline protease: molecular approaches and industrial applications. Appl. Microbiol. Biotechnol. 59: 15-32.

Heineken FG and O'Conner RJ 1972. Continuous cultural studies on the biosynthesis of alkaline protease, neutral protease and alpha-amylase by Bacillus subtilis NRRL-B3411. J. Gen. Microbiol. 73: 35-44.

Homma M, Chibana H and Tanaka K 1993. Induction of extracellular proteinase in Candida albicans. J. Gen. Microbiol. 139: 1187-1193.

Horikoshi K 1996. Alkalophiles - from an industrial point of view. FEMS Microbiol. Rev. 18: 259-270.

Horikoshi K. 1971. Production of alkaline enzyme by alkalophilic organisms. Part 1. Alkaline protease produced by Bacillus No. 221. Agric. Biol. Chem. 35: 407-1414.

Joo HS, Kumar CG, Park GC, Kim KT, Paik SR and Chan CS 2002. Optimization of the production of an extracellular alkaline protease from Bacillus horikoshii. Process Biochem. 37: 139-144.

Kole MM, Draper I and Gerson DF 1988. Production of protease by Bacillus subtilis using simultaneous control of glucose and ammonium concentrations. J. Chem. Technol. Biotechnol. 41: 197-206.

Lambert M, Blanchin-Roland S, Le-Louedec F, Lepingle A and Gaillardisis C 1997. Genetic analylsis of regulatory mutants affecting synthesis of extracellular proteinases in the yeast Yarrowia lipolytica: Identification of a RIM101/pacC homolog. Mol. Cell Biol. 17: 3966-3976.

Magasanik B 1961. Catabolite repression. Cold Spring Harbor Sym. Quant. Biol. 26: 249-256.

Moracova J and Chaloupka J 1984. Regression of synthesis of extracellular and intracellular proteinases in Bacillus megaterium. Foilia Microbiol. 29: 273-281. 
Norazizah S, Sayangku NA, Raja NZR, Mahiran B and Abu BS 2005. Optimization of environmental and nutritional conditions for the production of alkaline protease by a newly isolated bacterium Bacillus cereus strain 146. J. appl. Sci. Res. 1: 1-8.

Olajuyigbe MF and Ajele JO 2005. Production dynamics of extracellular protease from Bacillus sp. African Journal of Biotechnology 4: 776-779.

Prakasham RS, Subba Ch R, Sreenivas RR, Rajesham S and Sarma PN 2002. Optimization of the critical medium components for the production of alkaline protease from a newly isolated Bacillus subtilis PE11. J. Pharm. Sci. 5: 281-287.

Priest FG 1977. Extracellular enzyme synthesis in the genus Bacillus. Bacteriol. Rev. 41: 711-753.

Takii Y, Kuriyama N and Suzuki Y 1990. Alkaline serine protease produced from citric acid by Bacillus alcalophilus subsp. $h$ aloduran KP1239. Appl. Microbiol. Biotechnol. 34: 57-62.

Tsuchiya K, Kimura T 1984. Decrease of protease activity by the addition of glucose to the culture of Cephalosporium sp. J. Ferment. Technol. 62: 35-39.

Varela H, Ferrari MD, Belobradjic L, Weyrauch R and Loperena ML 1996. Effect of medium composition on the production of a new Bacillus subtilis isolate of protease with promising unhairing activity. World J. Microbiol. Biotechnol. 12: 643-645.

(Manuscript received on 28 August, 2012; revised on 19 March, 2015) 